E-ISSN. 2685-7650

Vol. 2 No. 1 (2020), pp 67-79

DOI: https://doi.org/10.33366/jkn.v2i1.37

\title{
Strategi Pemasaran TVRI dalam Menaikkan Brand Image
}

\author{
Christina \\ Program Studi Ilmu Komunikasi, Universitas Bunda Mulia \\ Email: ctandaju@bundamulia.ac.id
}

\begin{abstract}
Televisi Republik Indonesia (TVRI) is a state television. Since its establishment on August 24, 1962, TVRI has indeed experienced various phases in its life. Through Law No.32 of 2002 concerning Broadcasting, TVRI was established as a Public Broadcasting Institution (LPP). LPP is a broadcasting institution in the form of a legal entity established by the state, independent, neutral, non-commercial and functions to provide services for the benefit of the community. At present, TVRI has changed its Director since March 2018 namely Helmi Yahya, known as the King of Quiz. With the new Managing Director, TVRI began many enthusiasts who watched with new faces and more interesting programs. This research uses a qualitative research method, and is descriptive in nature which will later explain the marketing strategy of TVRI which has begun to attract the public and an increase in rating and audience share. This study uses interview techniques and data collection from social media and the internet as well as journals, books as primary and secondary data. The marketing strategy undertaken by TVRI includes five rebranding media including channel branding packages, promo on air, news packages, social media, and off air promotions. Of all the rebranding media, the most effective media is social media because aside from being a new media or digital marketing, it can reach all people, both TVRI viewers and private $T V$ viewers.
\end{abstract}

Keywords: TVRI, strategy, marketing, mass media, brand image

\begin{abstract}
Abstrak: Televisi Republik Indonesia (TVRI) merupakan televisi pemerintah. Sejak berdiri pada 24 Agustus 1962, TVRI memang telah mengalami berbagai fase dalam kehidupannya. Melalui UU No.32 Tahun 2002 tentang Penyiaran, TVRI ditetapkan sebagai Lembaga Penyiaran Publik (LPP). LPP adalah lembaga penyiaran yang berbentuk badan hukum didirikan oleh negara, bersifat independen, netral, tidak komersial dan berfungsi memberikan layanan untuk kepentingan masyarakat. Saat ini, TVRI sudah berganti Direktur Utama sejak Maret 2018 yaitu Helmi Yahya yang dikenal sebagai Raja Kuis. Dengan adanya Dirut yang baru, TVRI mulai banyak peminat yang menonton dengan wajah baru dan program-program yang lebih menarik. Penelitian ini menggunakan metode penelitian kualitatif, dan bersifat deskriptif yang nantinya akan memaparkan mengenai strategi pemasaran dari TVRI yang mulai diminati masyarakat dan adanya kenaikan rating dan share audience. Penelitian ini menggunakan teknik wawancara dan pengumpulan data dari media sosial dan internet serta jurnal, buku sebagai data primer dan sekunder. Strategi pemasaran yang dilakukan oleh TVRI meliputi lima media rebranding meliputi channel branding package, promo on air, news package, media sosial, dan promosi off air. Dari semua media rebranding, media yang paling efektif adalah media sosial karena selain sebagai media baru atau digital marketing, dapat menjangkau semua masyarakat baik penonton TVRI maupun penonton TV swasta.
\end{abstract}

Kata kunci: TVRI, strategi, pemasaran, media massa, citra

\section{Pendahuluan}

Dilansir dari aktual.com,Televisi Republik Indonesia (TVRI) merupakan televisi pemerintah. Sejak berdiri pada 24 Agustus 1962. TVRI memang telah mengalami berbagai fase dalam kehidupannya. Melalui UU No.32 Tahun 2002 tentang Penyiaran, TVRI ditetapkan sebagai Lembaga Penyiaran Publik (LPP). LPP adalah lembaga penyiaran yang berbentuk badan hukum didirikan oleh negara, bersifat independen, netral, tidak komersial dan berfungsi memberikan layanan untuk kepentingan masyarakat. Berdasarkan PP No.13 Tahun 2005, tugas TVRI adalah memberikan pelayanan informasi, pendidikan dan hiburan yang sehat, kontrol dan perekat sosial 


\section{Jurnal Komunikasi Nusantara}

\section{E-ISSN. 2685-7650}

Vol. 2 No. 1 (2020), pp 67-79

DOI: https://doi.org/10.33366/jkn.v2i1.37

serta melestarikan budaya bangsa untuk kepentingan seluruh lapisan masyarakat melalui penyelenggaraan penyiaran televisi yang menjangkau seluruh wilayah Negara Kesatuan Republik Indonesia. Dari Konminfo.go.id, Menurut Menteri Rudiantara, selama ini LPP TVRI mendapat penilaian disclaimer atas kinerja keuangan dari BPK empat kali berturut-turut hingga 2016. Selain itu, tantangan yang dihadapi LPP TVRI juga masalah sumberdaya manusia dan kebutuhan digitalisasi. "Migrasi ke digital yang memungkinkan pelayanan multiplatform, dan anggaran yang masih dari cukup", paparnya. Dilansir dari liputan6.com, keresahan ini sebenarnya ditanggap dengan baik dari pihak TVRI dengan ditunjuknya sosok Helmy Yahya Direktur Utama TVRI. Penujukan ini tergolong positif bila kita melihat rekam jejak Helmy Yahya sebagai "raja kuis" dan reality show yang telah melalangbuana di televisi-televisi swasta tanah air. Penilaian mempertimbangkan beragam kriteria, seperti kepemimpinan, integritas, keberagaman, visi internasional, program prioritas, jejaring, pemikiran strategis, kualitas konsep dan program kerja, inovasi, serta keberanian melakukan perubahan. Di sebuah wawancara ia mengatakan bahwa dirinya dan direksi terkait akan merubah TVRI dalam waktu setidaknya 2 tahun. Menarik untuk memperhatikan bagaimana strategi yang diterapkan direksi baru di bawah kepemimpinan Helmy Yahya ini.

State of the arts penelitian ini adalah Strategi Humas TVRI dalam Memperbaiki Citra TVRI di Mata Publik yang diteliti oleh Wina Puspita Sari dan Indah Nursyamsiah dari Jurnal Komunikasi, Journal UNJ 2013 yang menggunakan metode kualitatif, analisis deskriptif dengan menjelaskan Strategi yang di gunakan oleh Humas TVRI dalam rangka memperbaiki citra TVRI tehadap dua bentuk strategi yaitu strategi komunikasi (penyampaian informasi) dan strategi tindakan. Strategi komunikasi dilakukan dalam melalui media relations dalam bentuk press confrence, press release, sedangkan strategi tindakan yaitu perbaikan teknis, perubahan logo, bakti sosial (baksos), membuat program acara yang semenarik mungkin. Dengan metode atau pendekatan yang bersifat informatif, edukatif, operasional dan tanggung jawab sosial. Yang kedua adalah Studi Kasus Implementasi Kebijakan Reposisi Sumber Daya TVRI Pada Target Audience Generasi Milenial yang diteliti oleh Christina, Sandy Alifiansyah dan Rustono Farady Marta dari Jurnal Promedia 2019 menggunakan metode kualitatif, analisis deskriptif dengan menjelaskan TVRI telah merebranding serta mereposisi kembali sebagai TV publik dengan merebranding logo menjadi lebih milenial, perekrutan dan regenerasi SDM non PNS yang milenial berkolaborasi dengan PNS kolonial, perubahan yang cukup signifikan dari SDM, target market dan konten TVRI yang menjadi lebih milenial, peralatan yang diperbaharui, monster program yang membuat TVRI mendapatkan kembali penontonnya dan menambah penontonnya. Yang ketiga adalah Perencanaan Strategi Public Relations Garuda Indonesia dalam Membangun Kepercayaan Konsumen yang diteliti oleh Budi Darmawan, Nindira Cahyani, dan Melisa Arisanty dalam MetaCommunication, Journal of Communication Studies 2019 menjelaskan Garuda Indonesia melibatkan beberapa konsep yaitu Garuda Indonesia Experience, melakukan analisis situasi dengan melihat apa yang sedang trend untuk membentuk citra positif supaya bisa diterima masyarakat yang dapat mempengaruhi keputusan untuk menggunakan jasa Garuda Indonesia, untuk membangun brand awareness melakukan full service, dalam menyampaikan pesan mengambil dari sisi kemanusiaan.

Penelitian ini berbeda dengan penelitian yang lain atau kebaruan penelitian ini karena melihat dari strategi pemasaran atau humas dalam menaikkan brand image dari TVRI ketika memulai rebranding. Hal ini menjadi menarik bagi peneliti karena TVRI mengalami kenaikan $150 \%$ share audience dari TVRI yang sebelumnya. TVRI merebranding kembali dengan 


\section{Jurnal Komunikasi Nusantara}

\section{E-ISSN. 2685-7650}

Vol. 2 No. 1 (2020), pp 67-79

DOI: https://doi.org/10.33366/jkn.v2i1.37

meluncurkan logo baru dan juga program-program yang menarik generasi millenial. Dengan adanya Direktur Utama yang baru, Maret 2018 banyak tahapan berubahan yang terjadi baik secara eksternal dan internal. Berdasarkan data dari Puslitbang TVRI 2019, dengan adanya program-program yang baru, adanya kenaikan rating dan share dari acara olahraga yang disiarkan. Berdasarkan hal tersebut, tujuan penelitian ini adalah ingin melihat mengenai strategi pemasaran TVRI dalam menaikkan brand image yang berkaitan dengan kenaikan rating dan share penonton.

\section{Kajian Pustaka}

Strategi public relations akan membantu menciptakan reputasi perusahaan, sehingga akan mendukung tercapainya sasaran perusahaan dalam aspek pemasaran, pangsa pasar yang menjadi sasaran. Untuk itu, suatu strategi public relations yang baik harus menerjemahkan posisi perusahaan yang dikehendaki. Pesan yang disampaikan ke kelompok masyarakat yang merupakan sasaran pemasaran, harus tepat isu maupun suasananya. Pemilihan media dan waktunya, akan merupakan pertimbangan yang sangat berarti. Ini berhubungan dengan cara yang dipilih untuk menyampaikan pesan. Yang pasti, pesan akan disampaikan bertujuan agar masyarakat atau kelompok masyarakat atau konsumen mempunyai pemahaman tentang perusahaan atau institusi, yang konsekuensi logis terhadap produk atau jasa yang ditawarkan (Afdhal, 2008: 27 dalam Darmawan dkk, 2019: 251). Ahmad S. Adnanputra, M.A., M.S., pakar Humas dalam naskah workshop berjudul PR Strategy (1990), mengatakan bahwa arti strategi adalah bagian terpadu dari suatu rencana (plan), sedangkan rencana merupakan produk dari suatu perencanaan (planning), yang pada akhirnya perencanaan adalah salah satu fungsi dasar dari proses manajemen. Pengertian dari strategi public relations adalah alternatif optimal yang dipilih untuk ditempuh guna mencapai tujuan public relations dalam kerangka suatu rencana public relations (public relations plan). Public relations bertujuan untuk menegakkan dan mengembangkan suatu "citra yang menguntungkan" (favorable image) bagi organisasi/perusahaan, atau produk barang dan jasa terhadap para stakeholdersnya sasaran yang terkait yaitu publik internal dan publik eksternal. Untuk mencapai tujuan tersebut, strategi kegiatan PR semestinya diarahkan pada upaya menggarap persepsi para stakeholder, akar sikap tindak dan persepsi mereka. Konsekuensinya, jika strategi penggarapan itu berhasil maka akan diperoleh sikap tindak dan persepsi yang menguntungkan dari stakeholders sebagai khalayak sasaran. Pada akhirnya akan tercipta suatu opini dan citra yang menguntungkan. Strategi public relations dibentuk melalui dua komponen yang saling terkait erat, yakni sebagai berikut.

Tabel 1. Komponen Pembentukan Strategi PR

\begin{tabular}{lll}
\hline \multicolumn{2}{c}{ Komponen } & Pembentukan Strategi PR \\
\hline 1 & Komponen sasaran & Satuan atau segmen yang akan digarap \\
2 & Komponen sarana & Paduan atau bauran sarana untuk menggarap suatu sasaran \\
\hline
\end{tabular}

Sumber. Soemirat dan Ardianto (2012) 


\section{Jurnal Komunikasi Nusantara}

\section{E-ISSN. 2685-7650}

Vol. 2 No. 1 (2020), pp 67-79

DOI: https://doi.org/10.33366/jkn.v2i1.37

Adapun tahap-tahap kegiatan strategi public relations: pertama, komponen sasaran, umumnya adalah para stakeholder dan publik yang mempunyai kepentingan yang sama. Sasaran umum tersebut secara struktural dan formal yang dipersempit melalui upaya segmentasi yang dilandasi "seberapa jauh sasaran itu menyandang opini bersama (common opinion), potensi polemik, dan pengaruhnya bagi masa depan organisasi, lembaga, nama perusahaan dan produk yang menjadi perhatian sasaran khusus". Maksud sasaran khusus di sini adalah yang disebut publik sasaran (target publik). Kedua, komponen sarana (Adnanputra, 1990) yang pada strategi Public Relations berfungsi untuk mengarahkan ketiga kemungkinan tersebut ke arah posisi atau dimensi yang menguntungkan. Hal tersebut dilaksanakan melalui pola dasar "The 3-C's option" (Conservation, Change dan Crystallization) dari stakeholder yang disegmentasikan menjadi publik sasaran yaitu sebagai berikut.

Tabel 2. Komponen Strategi PR

\begin{tabular}{lll}
\hline \multicolumn{2}{c}{ Komponen } & Strategi Public Relations \\
\hline 1 & Mengukuhkan (conservation) & Terhadap opini yang aktif - Pro (Proponen) \\
2 & Mengubah (change) & Terhadap opini yang aktif - Contra (Oponen) \\
3 & Mengkristalisasi (crystallization) & Terhadap opini yang pasif (uncommited) \\
\hline
\end{tabular}

Sumber. Soemirat dan Ardianto (2012)

Contoh kasus yang dikaitkan dengan penjabaran strategi public relations tersebut di atas, yaitu suatu strategi PR yang mendukung manajemen perusahaan dalam menghadapi rencana karyawan yang akan mengadakan pemogokan, dan peran PR sebagai "radar" (early warning system) bagi organisasi. Kemudian tindakan berikutnya, adalah mengupayakan tindakan pencegahan (preventif) terjadinya pemogokan dengan "mengubah" sikap tindak dan opini pihak pekerja yang bersedia diajak berunding secara bipartit atau tripartit - melibatkan pihak perwakilan buruh, manajemen perusahaan atau pemerintahan. Hal yang paling sulit adalah mengubah atau mengkristalisaasi sikap tindak atau opini dari kelompok karyawan yang aktif-contra (oponen), walaupun jumlahnya kecil tetapi dengan "kevokalannya" untuk menyuarakan tuntutan secara lantang itu mereka mampu secara efektif mempengaruhi kelompok karyawan lainnya yang bersifat pasif (uncommited) (Ruslan, 2010, 133-136). Untuk dapat bertindak secara strategis, kegiatan PR harus menyatu dengan visi dan misi organisasi/perusahaannya. Sama seperti bagian divisi dan misi perusahaan, untuk memberi kontribusi kepada rencana kerja jangka panjang itu, praktisi PR dapat melakukan langkah-langkah:

1. Menyampaikan fakta dan opini, baik yang beredar di dalam maupun di luar perusahaan. Bahan-bahan itu dapat diperoleh dari kliping media massa dalam kurun waktu tertentu, dengan melakukan penelitian terhadap naskah-naskah pidato pimpinan, bahan yang dipublikasikan perusahaan, serta melakukan wawancara tertentu dengan pihak-pihak yang berkepentingan atau dianggap penting. 


\section{Jurnal Komunikasi Nusantara}

\section{E-ISSN. 2685-7650}

Vol. 2 No. 1 (2020), pp 67-79

DOI: https://doi.org/10.33366/jkn.v2i1.37

2. Menelusuri dokumen resmi perusahaan dan mempelajari perubahan yang terjadi secara historis. Perubahan umumnya disertai dengan perubahan sikap perusahaan terhadap publiknya atau sebaliknya.

3. Melakukan analisis SWOT. Meski tidak perlu menganalisis hal-hal yang berada di luar jangkauannya, seorang praktisi PR perlu melakukan analisis yang berbobot mengenai persepsi dari luar dan dalam perusahaan atas SWOT yang dimilikinya. Misalnya menyangkut masa depan industri yang ditekuninya, citra yang dimiliki perusahaan, kultur yang dimiliki serat potensi lain yang dimiliki perusahaan (Soemirat dan Ardianto, 2012: 90-91).

Pembentukan strategi dalam menangani suatu permasalahan yang berkaitan dengan manusia diharuskan memahami berbagai aspek, ketika melakukan proses komunikasi beberapa konsep dalam diterapkan salah satunya adalah konsep AIDA (Attention-mendapatkan perhatian, Interest-mempertahankan ketertarikan, Desire - menumbuhkan keinginan dan Action-menghasilkan tindakan). Mendapatkan perhatian (Attention) merupakan tujuan utama dalam mempraktekan konsep AIDA ini, karena perhatian adalah dasar dimana kita memperoleh peluang untuk melanjutkan ke tahap selanjutnya dalam proses ketertarikan, dengan mendapatkan perhatian seoarang PR mampu mempegaruhi dengan cara retorika yang tidak terlalu sulit.Mempertahankan ketertarikan (Interest) merupakan hal yang tersulit dalam konsep AIDA karena seorang PR harus pandai bermain dengan pemikiran dan cara dia mengolah teknik retorika untuk selalu mendapat perhatian yang diinginkan. Seorang PR harus mampu memanipulasi keadaan untuk menyampaikan apa maksud dan tujuan yang harus disampaikan dan memikirkan strategi apa yang harus diucapkan dalam proses retorika sehingga pesan yang disampaiakan bisa tersalurkan sesuai dengan apa yang ingin disampaikan. Menumbuhkan keinginan (Desire) juga merupakan hal yang tidak mudah karena seorang PR dalam menangani suatu persoalan dalam kaitannya dengan komunikasi, harus benarbenar memahami kondisi yang terjadi di lapangan agar proses penyampaian informasi dapat tersampaikan. Teknik ini merupakan teknik permainan emosi, jika PR mampu membangkitkan emosi dalam proses retorika saat itulah keinginan akan terjadi.Menghasilkan tindakan (Action) adalah tugas terakhir dari seorang PR, dan juga buka sesuatu yang mudah, ketika semua teknik dalam AIDA dapat dijalankan, hal inilah yang akan menentukan apakah cara retorika kita berhasil atau tidak, karena tujuan dari AIDA ini adalah tahap terakhir pada konsep ini yaitu menghasilkan tindakan. Hal ini dapat menolong dan membantu berbagai macam program-program PR dalam melakukan sesuatu untuk menumbuhkembangkan kesadaran dalam masyarakat untuk melakukan sesuatu demi tercapainya tujuan yang diinginakan dengan hasil yang positif (Cannon, dkk. 2009).

Menurut Bill Canton dalam Sukatendel (1990) mengatakan bahwa citra adalah "image: the impression, the feeling, the conception which the public has of a company; a concioussly created impression of on object, person or organization" (Citra adalah kesan, perasaan, gambaran dari publik terhadap perusahaan; kesan yang dengan sengaja diciptakan dari suatu obyek, orang atau organisasi) (Soemirat\&Adrianto, 2004:111 dalam Sari \& Nursyamsiah, 2017:6). Citra adalah tujuan utama, dan sekaligus merupakan reputasi dan prestasi yang hendak dicapai bagi dunia hubungan masyarakat (kehumasan) atau public relations. Penilaian atau tanggapan masyarakat tersebut dapat berkaitan dengan timbulnya rasa hormat (respek), kesan-kesan yang baik dan menguntungkan terhadap suatu citra lembaga atau organisasi atau produk barang dan jasa pelayanan yang diwakili oleh pihak humas (PR) (Ruslan,2007:75-76 dalam Sari \& Nursyamsiah, 2017:6-7). Citra terbentuk berdasarkan pengetahuan dan informasi yang diterima seseorang. 


\section{Jurnal Komunikasi Nusantara}

\section{E-ISSN. 2685-7650}

Vol. 2 No. 1 (2020), pp 67-79

DOI: https://doi.org/10.33366/jkn.v2i1.37

Komunikasi tidak secara langsung menimbulkan perilaku tertentu, tetapi cenderung mempengaruhi cara kita mengorganisasikan citra kita tentang lingkungan. Proses pembentukan citra dalam struktur kognitif yang sesuai dengan pengertian sistem komunikasi dijelaskan oleh John S. Nipoeno, dalam laporan penelitian tentang Tingkah Laku Konsumen, seperti yang dikutip Danasaputra, sebagai berikut:

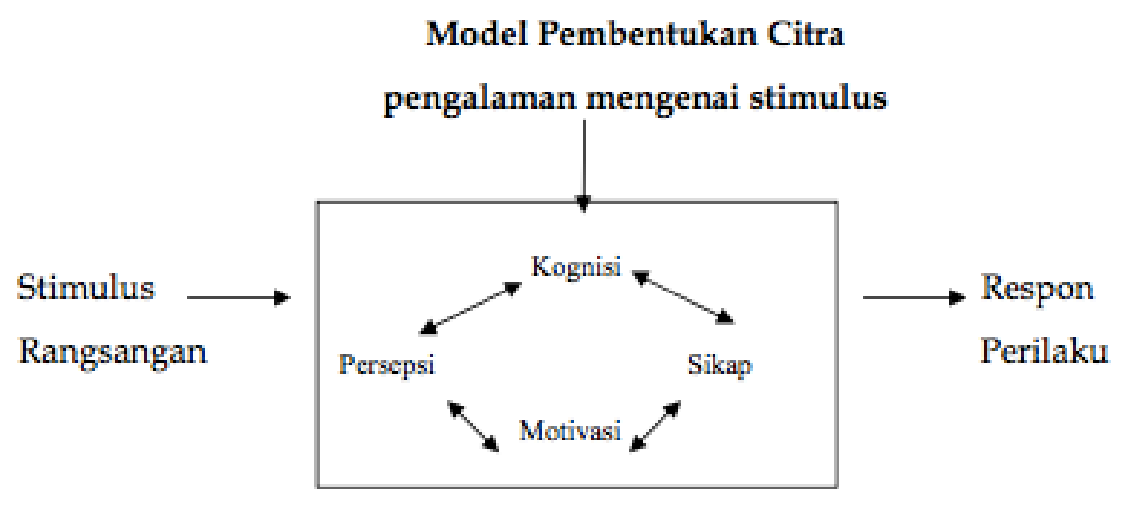

Gambar 1. Model Pembentukan Citra

Sumber. Soemirat, 2004 dalam Sari \& Nursyamsiah, 2017

Public Relations digambarkan sebagai input-output, proses intern dalam model ini adalah pembentukan citra, sedangkan input adalah stimulus yang diberikan dan output adalah tanggapan atau perilaku tertentu. Citra itu sendiri digambarkan melalui persepsi kignisi-motivasi-sikap. Model pembentukan citra ini menunjukan bagaimana stimulus yang berasal dari luar dioragnisasikan dam mempengaruhi respons. Stimulus (rangsang) yang diberikan pada individu dapat diterima atau ditolak (Soemirat\&Adrianto, 2004 dalam Sari \& Nursyamsiah, 2017).

\section{Metode Penelitian}

Penelitian ini dimulai dari repositioning dan rebranding TVRI Maret 2018, dan adanya kenaikan rating dan share audience dengan adanya perluasan target audience ke generasi milenial. Setelah itu, peneliti memastikan urgensi penelitian, mencari dan memastikan penelitian ini belum pernah diteliti oleh peneliti lain, kemudian mencari serta mengumpulkan data selengkap-lengkapnya mengenai TVRI dan program-program yang dibuat. Langkah berikutnya, tujuan \& manfaat penelitian serta hasil dan luaran yang dicapai. Teori serta konsep diuji dengan hasil temuan yang ada, kemudian hasil yang ditemukan dapat menjadi evaluasi serta dapat dikembangkan selanjutnya lewat simpulan dan saran.Peneliti juga memposisikan diri sebagai pihak netral, tidak memihak, supaya hasil penelitian ini objektif.Obyek penelitiannya adalah TVRI, melihat dari rating dan share yang naik dari bulan ke bulan serta dari Maret 2018 - 2019. Teknik pengumpulan data yang dipakai peneliti adalah wawancara dan analisis. Data sekunder diperoleh dari website, penelitian sejenis yang terdahulu berupa rujukan penelitian sebelumnya yang menunjang informasi yang dibutuhkan untuk melengkapi penelitian ini. Analisis data kualitatif menurut Miles dan Huberman dilakukan secara interaktif melalui proses data reduction, data display, dan verification. Sedangkan menurut Spradley dilakukan secara berurutan, melalui proses analisis domain, taksonomi, komponensial, 


\section{Jurnal Komunikasi Nusantara}

\section{E-ISSN. 2685-7650}

Vol. 2 No. 1 (2020), pp 67-79

DOI: https://doi.org/10.33366/jkn.v2i1.37

dan tema budaya (Sugiyono, 2009: 147). Penelitian ini menggunakan metode analisis deskriptif yang nantinya hasil wawancara akan diolah dengan teori strategi public relations dan AIDA.

Menurut Andi Prastowo, penelitian kualitatif merupakan satu kegiatan sistematis untuk menemukan teori dari kancah (lapangan), bukan untuk menguji teori atau hipotesis (Prastowo, 2011).

\section{Hasil dan Pembahasan}

Sebelumnya TVRI dikenal sebagai TV jadul yang ditonton oleh audience yang berusia kisaran 40 tahun, sudah ditinggalkan pemirsanya. Pada Maret 2018 sampai sekarang yang diiringi oleh masuknya direksi baru, TVRI melakukan rebranding dimulai dari rebranding logo sebagai sumber referensi terpercaya dan media pemersatu bangsa di masa depan; motto Direktorat Umum yaitu PRIMA (Profesional, Ramah, Informatif, Melayani, Akuntabel); nilai-nilai baru APIK (Adaptif, Positif, Informatif, Kreatif); dan visinya menjadi "Media Pemersatu Bangsa" dengan misi "World Class Public Broadcasting". Sasaran TVRI adalah dapat melayani semua usia, menjadi media yang terpercaya, imparsial, terupdate yang dilengkapi dengan peralatan teknologi yang canggih, selain itu dapat memberikan informasi, hiburan, dan pendidikan. Adanya kolaborasi antara kolonial dan milenial atau PNS dengan non-PNS yang menjadikan TVRI menjadi TV publik yang dapat bertahan di industri kreatif. Dengan adanya rebranding, adanya keseimbangan audience yang menonton TVRI yaitu antara usia 20-30 tahun dan 30-40 tahun. TVRI juga membuat Majalah TVRI (Monitor) yang berisi tentang perubahan-perubahan yang terjadi di TVRI yang disebarkan kepada tim TVRI supaya pekerja mengenal lebih lagi dan mengerti visi misi TVRI yang baru serta mengikuti perkembangan dan acara-acara internal. Kemudian tim TVRi juga membuat buku panduan untuk rebranding logo TVRI dan perubahan-perubahan yang dilakukan TVRI yang disebarkan kepada para atasan atau pejabat di TVRi serta tim humas. Hal ini dilakukan supaya tim TVRI dapat menjawab satu suara jika mendapat pertanyaan seputar TVRI karena TVRI membuka peluang untuk teman-teman yang melakukan penelitian. Adanya \#kamikembali caranya merubah program yang ada di TVRI dengan memilih program yang paling diminati pemirsa sekarang yaitu badminton dan sepakbola. Dalam menghadapi prokontra atau opini negatif dari audience di media sosial, admin media sosial yang senior memberikan jawaban resmi dan sopan dengan alasan yang jelas dikarenakan admin media sosial dibagi menjadi dua yaitu admin medsos instagram yang lebih milenial ditangani oleh staf ahli atau non-PNS sedangkan medsos twitter yang lebih resmi atau dengan text yang terbatas dibantu oleh PNS serta komentar-komentar negatif ditangani oleh tim TVRI.

Kekuatan dari TVRI adalah satu-satunya TV publik yang ada di Indonesia sebagai TV non komersil, tetapi masih bisa mendapatkan pendapatan dari iklan dengan batas atau limit tertentu sesuai dengan aturan. Sebagai lembaga penyiaran publik yang mempunyai misi yaitu edukasi, memberikan informasi, dan menghibur. Selain itu, Dirut Helmy Yahya memiliki kekuatan dalam melobby serta dikenal masyarakat sebagai Raja Kuis. Kelemahannya dari TVRI yaitu financial management \& aacountability, HR management, old equipment, lack of creativity, poor production executive, very low stakeholder's trust, not milenial enough. Peluang yang dimiliki TVRI adalah dengan adanya Dirut yang baru, TVRI bisa menjadi lebih baik dan sebagai pemimpin, harus terlihat dan menjadi teladan, sehingga saat ini para karyawan TVRI bisa bersama-sama untuk bangkit dan adanya rasa memiliki, di daerah juga perekrutan dari orang lokal supaya ada rasa 


\section{Jurnal Komunikasi Nusantara}

\section{E-ISSN. 2685-7650}

Vol. 2 No. 1 (2020), pp 67-79

DOI: https://doi.org/10.33366/jkn.v2i1.37

memiliki dan menjaga aset serta pelestarian budaya lokal yang ada. Kolaborasi milenial dan kolonial yang saat ini dilakukan. Ancaman yang akan dihadapi TVRI yaitu perubahan yang akan terus terjadi sehingga TVRI harus siap dengan perubahan tersebut. Yang sudah disiapkan TVRI ke depannya adalah perpindahan dari sistem analog ke digital sudah disiapkan TVRI. TVRI dalam menarik perhatian audience melakukan promosi lewat media sosial dari TVRI, Helmi Yahya dan juga Apni Jaya kemudian mengetahui acara apa yang menjadi penarik perhatian audience dan setelah di riset oleh tim riset TVRI (puslitbang) yang menjadi favorit penonton adalah olahraga serta edukasi sehingga TVRI menampilkan monster program olahraga seperti sepakbola dan bulutangkis.

\section{a. Strategi Public Relations}

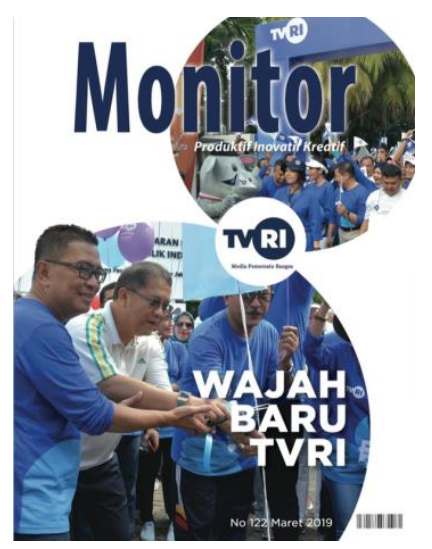

Gambar 2. Monitor (Majalah TVRI)

Sumber. Tim Humas TVRI (2019)

Sebelumnya TVRI dikenal sebagai TV jadul yang ditonton oleh audience yang berusia kisaran 40 tahun, sudah ditinggalkan pemirsanya. Pada Maret 2018 sampai sekarang yang diiringi oleh masuknya direksi baru, TVRI melakukan rebranding dimulai dari rebranding logo yang memiliki makna sebagai Lingkaran Penyambung Dunia yaitu satu siaran, satu suara, satu Indonesia untuk dunia, sedangkan warna biru yang diibaratkan simbol lautan Indonesia yang penuh kekayaan sebagai sumber referensi terpercaya dan media pemersatu bangsa di masa depan; motto Direktorat Umum yaitu PRIMA (Profesional, Ramah, Informatif, Melayani, Akuntabel); nilai-nilai baru APIK (Adaptif, Positif, Informatif, Kreatif); dan visinya menjadi "Media Pemersatu Bangsa" dengan misi "World Class Public Broadcasting". Dalam pembentukan strategi PR, komponen sasaran TVRI adalah dapat melayani semua usia, menjadi media yang terpercaya, imparsial, terupdate yang dilengkapi dengan peralatan teknologi yang canggih, selain itu dapat memberikan informasi, hiburan, dan pendidikan. Adanya kolaborasi antara kolonial dan milenial atau PNS dengan non-PNS yang menjadikan TVRI menjadi TV publik yang dapat bertahan di industri kreatif. Dengan adanya rebranding, adanya keseimbangan audience yang menonton TVRI yaitu antara usia 20-30 tahun dan 30-40 tahun. Komponen sarana TVRI dalam strategi public relations yaitu TVRI yang melakukan rebranding membuat tim, buku panduan rebranding yang disertai lengkap dengan keterangan mengenai filosofi logo TVRI yang mendukung visi misi. Kemudian 


\section{Jurnal Komunikasi Nusantara}

\section{E-ISSN. 2685-7650}

Vol. 2 No. 1 (2020), pp 67-79

DOI: https://doi.org/10.33366/jkn.v2i1.37

dengan adanya nilai-nilai baru serta perekrutan, Helmy Yahya sebagai direktur utama beserta jajaran menjadi teladan dan menjadi contoh bagi karyawan lainnya serta membuat kolaborasi antara PNS dan non-PNS supaya dapat bersinergi serta memajukan TVRI. Kemudian dari wawancara dengan narasumber, adanya \#kamikembali caranya merubah program yang ada di TVRI dengan memilih program yang paling diminati pemirsa sekarang yaitu badminton dan sepakbola.

Dalam menghadapi prokontra atau opini negatif dari audience di media sosial, admin media sosial yang senior memberikan jawaban resmi dan sopan dengan alasan yang jelas dikarenakan admin media sosial dibagi menjadi dua yaitu admin medsos instagram yang lebih milenial ditangani oleh staf ahli atau non-PNS sedangkan medsos twitter yang lebih resmi atau dengan text yang terbatas dibantu oleh PNS serta komentar-komentar negatif ditangani oleh beliau. Contohnya seorang penggemar Liverpool, jika pertandingan Liverpool tidak disiarkan, akan berkomentar negatif atau marah. Kasusnya pengguna parabola di daerah yang tidak terjangkau oleh UHM, yang ingin menonton badminton tidak bisa karena diacak. Di twitter, komentarnya TVRI dibiayai APBN, tapi mengacak siaran parabola, dan semuanya benar tapi mereka tidak melihat alasannya. Yang berani menjawab hal seperti itu adalah admin senior dan sudah mendapat kepercayaan serta izin dari Pak Helmi \& Pak Apni untuk menjawab pertanyaan tersebut secara resmi. Kemudian jawaban yang kami berikan adalah dalam dunia broadcasting ada namanya perjanjian hak siar yaitu lewat platform apa \& coverage areanya dimana saja. Dengan penjelasan ini, audience yang berkomentar negatif tersebut tidak berkomentar lagi. Kekuatan dari TVRI adalah satu-satunya TV publik yang ada di Indonesia sebagai TV non komersil, tetapi masih bisa mendapatkan pendapatan dari iklan dengan batas atau limit tertentu sesuai dengan aturan. Sebagai lembaga penyiaran publik yang mempunyai misi yaitu edukasi, memberikan informasi, dan menghibur. Selain itu, Dirut Helmy Yahya memiliki kekuatan dalam melobby serta dikenal masyarakat sebagai Raja Kuis. Kelemahannya dari TVRI yaitu financial management \& aacountability, HR management, old equipment, lack of creativity, poor production executive, very low stakeholder's trust, not milenial enough. Peluang yang dimiliki TVRI adalah dengan adanya Dirut yang baru, TVRI bisa menjadi lebih baik dan sebagai pemimpin, harus terlihat dan menjadi teladan, sehingga saat ini para karyawan TVRI bisa bersama-sama untuk bangkit dan adanya rasa memiliki, di daerah juga perekrutan dari orang lokal supaya ada rasa memiliki dan menjaga aset serta pelestarian budaya lokal yang ada. Kolaborasi milenial dan kolonial yang saat ini dilakukan. Ancaman yang akan dihadapi TVRI yaitu perubahan yang akan terus terjadi sehingga TVRI harus siap dengan perubahan tersebut. Yang sudah disiapkan TVRI ke depannya adalah perpindahan dari sistem analog ke digital sudah disiapkan TVRI. Dari wawancara, narasumber lebih membahas mengenai promosi di media sosial twitter, facebook, dan instagram, sedangkan informasi lainnya, peneliti mendapatkan informasi dari tim humas dan juga buku panduan serta Majalah Monitor yang diberikan tim humas TVRI serta narasumber.

\section{b. Konsep AIDA}

Dalam menarik perhatian audience, TVRI sudah menjadi perhatian ketika adanya direktur utama yang baru yaitu Helmy Yahya yang dikenal di industri kreatif sebagai "Raja Kuis". Beberapa program yang telah beliau buat seperti Kuis Siapa Berani menjadi salah satu program di TVRI, kemudian Bedah Rumah, Kawin Massal. Program-program yang fenomenal dimana program tersebut membantu masyarakat Indonesia dan dikenal sebagai acara gratis. Dengan adanya 


\section{Jurnal Komunikasi Nusantara}

\section{E-ISSN. 2685-7650}

Vol. 2 No. 1 (2020), pp 67-79

DOI: https://doi.org/10.33366/jkn.v2i1.37

Helmy Yahya di TVRI, TVRI menjadi menarik perhatian para audience yang disertai dengan wajah baru TVRI yaitu dengan perubahan ulang logo TVRI yang ke-8, merupakan identitas baru serta wajah baru TVRI yang milenial. Langkah-langkah yang dilakukan oleh tim TVRI untuk mempertahankan ketertarikan tersebut lewat perubahan program-program yang dikemas lebih milenial dengan mempertahankan kearifan lokal, didukung oleh peralatan teknologi yang canggih, studio diperbaharui, serta promosi-promosi lewat media sosial baik dari media sosial TVRI maupun media sosial Helmy Yahya atau Apni Jaya yang sudah terverifikasi. Menumbuhkan keinginan untuk menonton TVRI mulai muncul dikarenakan program-program yang disuguhkan disesuaikan dengan minat dari masyarakat yaitu olahraga. Maka dari itu, TVRI menyiarkan program-program olahraga dengan bekerjasama seperti Mola TV yang menyiarkan monster program Premier League, dan lain-lain sehingga membuat TVRI dapat mengklaim sebagai Rumah Bulu Tangkis dan Rumah Sepak Bola. Tindakan yang dilakukan menggunakan lima rebranding yaitu:

- channel branding package : station ID digunakan untuk transisi program setiap jam yakni pukul 06.00 WIB, 09.00 WIB, 12.00 WIB, 15.00 WIB, 18.00 WIB, 21.00 WIB, dan 24.00 WIB

- promo on air : penerapan template pada promo program on air

- news package: bumper penanda program

- media sosial : akun medsos resmi TVRI Nasional : twitter, fanpage, youtube, instagram, website. Selain itu, bekerjasama juga dengan vidio.com yang merupakan platform SCTV yang perlu menjadi perhatian dan berhati-hati untuk selalu memberi logo TVRI dengan resolusi tinggi, dan cleanfit.

- promosi off air: billboard/baliho, umbul-umbul/banner, hoarding, merchandise

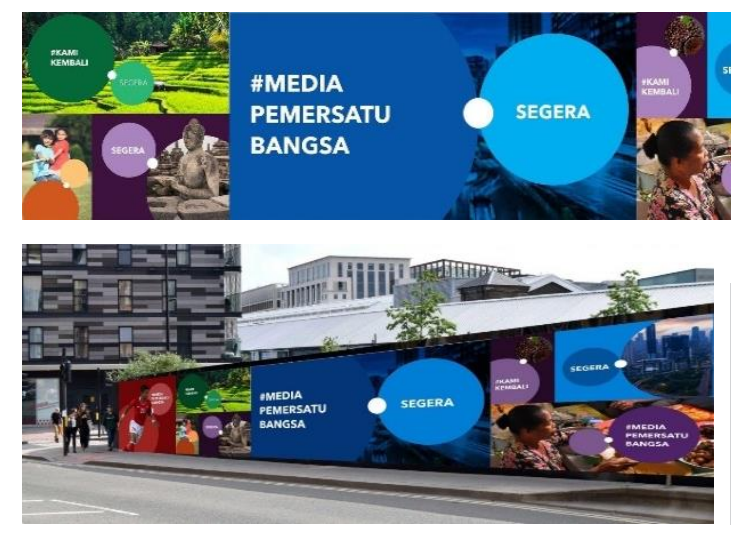

Gambar 3. Hoarding
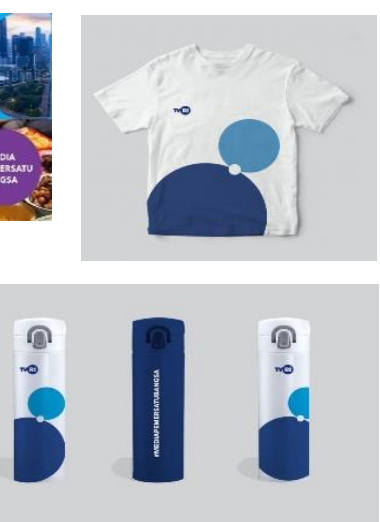

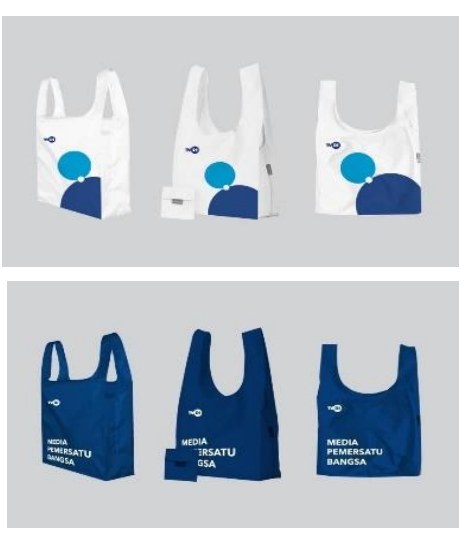

Gambar 4. Merchandise

Sumber. Manual E-book Rebranding TVRI (2019)

\section{c. Brand Image / Citra}

Landasan brand story TVRI yaitu beraspirasi menjadi media yang membangun masyarakat Indonesia (TVRI melakukan perubahan positif untuk berjalan beriringan dengan dinamika masyarakat Indonesia), menyoroti beragam kekayaan serta keindahan Indonesia dan mengolahnya menjadi konten yang membangun, konten positif dan edukatif (konten yang tidak hanya aktual dan faktual, tapi juga tidak memihak kepentingan golongan di Indonesia), menjadi pemersatu bangsa dan menyuarakan kehebatan Indonesia (suara yang memotivasi, menginspirasi, dan membanggakan nusantara hingga ke seluruh Indonesia). 


\section{Jurnal Komunikasi Nusantara}

\section{E-ISSN. 2685-7650}

Vol. 2 No. 1 (2020), pp 67-79

DOI: https://doi.org/10.33366/jkn.v2i1.37

Brand essence TVRI yaitu membawa kebanggaan Indonesia ke mata dunia dengan maksud TVRI adalah media publik dengan integritas tinggi untuk menyuarakan berbagai nilai, budaya, dan keberagaman yang menjadi kebanggan Indonesia melalui konten programnya yang berkualitas ke seluruh lapisan masyarakat hingga ke berbagai penjuru tempat.

Visi Misi TVRI yaitu "Menjadi world Class Broadcaster": menjadi media yang multimedia, multiplatform, dan multicanal; dapat dipercaya oleh publik; tidak tergantung oleh pemerintah.

Brand positioning dari TVRI adalah media layanan publik Indonesia yang terintegrasi di berbagai platform dengan hiburan yang mengangkat nilai, kebudayaan, dan keberagaman yang membanggakan Indonesia.

Dari landasan brand TVRI di atas, peneliti dapat menyimpulkan bahwa TVRI dengan \#kamikembali dan "We Fight Back" menyatakan dengan adanya dirut yang baru, TVRI ingin kembali ditonton oleh masyarakat Indonesia sesuai dengan fungsi penyiaran untuk mengedukasi, memberi informasi, dan menghibur penonton supaya TVRI menjadi TV publik yang dipercaya seperti TV publik di negara-negara lain (NHK) dan tidak kalah dengan TV swasta yang komersil dengan kemasan program yang diperbaharui mengikuti zaman serta melayani untuk semua golongan dengan tampilan yang berkualitas tidak seperti dulu dengan kolaborasi SDM. Dirut yang baru membuat identitas baru TVRI yang positif menjadi identitas yang lebih milenial dengan promosi yang efektif yaitu media sosial.

Model pembentukan citra TVRI dimulai dari stimulus yang dibuat TVRI dengan menampilkan logo baru TVRI (rebranding) yang terlihat milenial dan adanya perubahan pekerja TVRI termasuk yang dilihat adalah Dirut baru yaitu Helmy Yahya yang menjadi penarik audience. Dari stimulus ini, berdasarkan dari hasil observasi dan seminar yang dibuat oleh TVRI, banyak audience mendukung perubahan TVRI tapi ada juga yang memberi pandangan negatif mengenai logo TVRI yang dikatakan logo TVRI meniru logo TV Jerman atau DW, tetapi Helmy Yahya mengatakan bahwa logo TVRI sangat berbeda dengan logo tersebut dan logo TVRI mempunyai makna sebagai media pemersatu bangsa. Kemudian persepsi yang dimiliki TVRI sebagai kelemahan TVRI yaitu TV jadul menjadi evaluasi TVRI sehingga TVRI memiliki kemasan program yang milenial dan menarik sehingga persepsi dari audience sekarang bahwa TVRI sudah jauh berubah dan dapat bersaing dengan TV swasta serta program sekarang ingin ditonton yang terutama gambarnya bersih. Dengan program-program menarik, akhirnya membuat penonton menjadi menonton TVRI, mendapat pendidikan serta informasi dari TVRI dan hiburan yang menarik sehingga mengubah kognisi, motivasi, sikap dan akhirnya TVRI menjadi TV publik yang saat ini sudah layak ditonton dan aman ditonton oleh segala umur yang akhirnya ini menjadi respon perilaku dari audience yang sangat mendukung TVRI dan memberikan masukan-masukan yang baik untuk TVRI yang dapat dilihat dari komentar audience di media sosial dan mendukung \#kamikembali.

\section{Kesimpulan}

Kesimpulan dari penelitian ini adalah TVRI melakukan lima media rebranding yang meliputi channel branding package, promo on air, news package, media sosial, dan promosi off air (billboard/baliho, umbul-umbul/banner, hoarding, merchandise). Dari semua media rebranding, media yang paling efektif adalah media sosial karena dapat menjangkau semua masyarakat baik penonton TVRI maupun penonton TV swasta yaitu media sosial TVRI nasional dan juga media 


\section{Jurnal Komunikasi Nusantara}

\section{E-ISSN. 2685-7650}

Vol. 2 No. 1 (2020), pp 67-79

DOI: https://doi.org/10.33366/jkn.v2i1.37

sosial Bapak Helmy Yahya dan Bapak Apni yang terverified membantu kenaikan brand image TVRI saat rebranding. Kemudian adanya press conference setelah itu gebyar acara perubahan logo TVRI dengan konser musik menggapai dunia dan pagelaran wayang semalam suntuk tanggal 29 Maret 2019 yang dilakukan selama 7jam nonstop yang membuktikan kolaborasi generasi kolonial dan generasi milenial bisa bersatu dan mendukung \#kamikembali.

Saran dari penelitian ini adalah pemasaran dapat dilakukan lebih maksimal jika adanya dana yang lebih, serta kebebasan ruang gerak untuk berkreasi dan lebih fleksibel.

\section{Daftar Pustaka}

Aktual. (2016). TVRI sebagai Lembaga Penyiaran Publik Mau Dibawa ke Mana? diambil dari http://www.aktual.com/tvri-lembaga-penyiaran-publik-mau-dibawa-mana/ diakses 29 September 2019.

Ardianto, Elvinaro. (2014). Metode Penelitian untuk Public Relations Kuantitatif dan Kualitatif. Bandung: Simbiosa Rekatama Media

Cannon, P. Perreault, D, W \& McCarthy, J, E. (2009). Pemasaran Dasar. Jakarta: Salemba Empat. Christina, Alifiansyah, Sandy \& Martha, Rustono Farady. (2019). Studi Kasus Implementasi Kebijakan Reposisi Sumber Daya TVRI Pada Target Audience Generasi Milenial. Jurnal Promedia, 5(2), 55-88.

Darmawan, B, Cahyani, N, Arisanty, M. (2019). Perencanaan Strategi Public Relations Garuda Indonesia dalam Membangun Kepercayaan Konsumen. MetaCommunications; Journal of Communication Studies. Jakarta: PT Gramedia Widiasarana Indonesia.

Ishadi. (2012). TVRI Mau ke Mana? diambil dari https://nasional.kompas.com/ diakses 16 Mei 2018: Kompas.com

Haryanto, Andry. (2017). Helmy Yahya Pimpin TVRI Periode 2017-2022. diambil dari https://www.liputan6.com/news/read/3177287/helmy-yahya-pimpin-tvri-periode-20172022. diakses 29 September 2019.

Hutabarat, Diani. (2017). Menkominfo Harap Dewan Pengawas LPP TVRI Benahi Internal. diambil dari https://www.kominfo.go.id/content/detail/10066/lantik-dewas-lpp-tvri-menkominfo-harapkan-pembenahan-internal/0/berita_satker diakses 29 September 2019.

Kombaitan, Yuliana. (2013). Implementasi Kebijakan TVRI Dalam Meningkatkan Kualitas Penyiaran Program. Jurnal Eksekutif, 2(1). Diambil dari http://ejournal.unsrat.ac.id/index.php/jurnaleksekutif/article /download/2686/2239 diakses 22 Agustus 2018: Unsrat.

Marta, Rustono Farady \& Septyana, Virgitta. (2015). Semiotika Pemasaran Pada Brand Value Melalui Sign Berupa Layout Berita Dan Iklan Ibadah Haji. Semiotika: Jurnal Komunikasi, 9(2). Diambil dari https://journal.ubm.ac.id/index.php/semiotika/article/view/2 4 diakses 30 Oktober 2019: Universitas Bunda Mulia.

Prastowo, Andi. (2011). Metode Penelitian Kualitatif: dalam Prespektif Rancangan Penelitian. Jogyakarta: Ar- Ruzz Media.

Ruslan, Rosady. (2010). Manajemen Public Relations\&Media Komunikasi. Jakarta: PT Raja Grafindo Persada.

Sari, Wina Puspita dan Indah Nursyamsiah. (2013). Strategi Humas TVRI dalam Memperbaiki Citra TVRI Di Mata Publik. Communicology: Jurnal Ilmu Komunikasi, 1(1), 1-19. 


\section{Jurnal Komunikasi Nusantara}

\section{E-ISSN. 2685-7650}

Vol. 2 No. 1 (2020), pp 67-79

DOI: https://doi.org/10.33366/jkn.v2i1.37

Soemirat, Soleh dan Ardianto, Elvinaro, (2012). Dasar-Dasar Public Relation. Bandung: PT Remaja Rosdakarya Offset

Sugiyono. (2009). Metode Penelitian Bisnis (Pendekatan Kuantitatif, Kualitatif, dan R\&D). Bandung: Alfabeta. 